\title{
The Impact of Private Sector Provision of Home-Based Services for Older People in Beijing
}

\author{
Rui Kang ${ }^{1, *}$, George Leeson ${ }^{2}$, Laurel Hixon ${ }^{2}$ \\ ${ }^{1}$ School of Labour Economics, Capital University of Economics and Business, Beijing 100070, China; \\ ${ }^{2}$ Oxford Institute of Population Ageing, University of Oxford, Oxford OX2 6PR, UK
}

\begin{abstract}
The private sector in China plays an increasingly important role in the provision of home-based services for older people as the number of older people and their care and support needs increase. However, Public-Private Partnership (PPP) is relatively new in Beijing. This paper explores the relationship between the use of and the satisfaction with home-based services for older people provided by the private sector on the one hand and the finance, regulation, private sector conditions, and an individual's situation on the other hand. The analyses make use of both the statistics data and survey data. The results of the analyses suggest that use of these services is affected by the coverage of the private sector and professional staff, the older person's pension and number of their children. In addition, satisfaction with services is influenced by financial contribution from the local authority as well as the level of regulations on subsidies, the coverage of the private sector and professional staff, and the older person's expenditure. In conclusion, in order to further improve and develop PPP in the provision of home-based services for older people in Beijing, we suggest that policy should focus on the expansion of service providers and professionals to increase the coverage. In addition, local authorities should be involved financially, especially in subsidies for older people based on means-testing.
\end{abstract}

Keywords: Public-Private Partnership; home-based services for older people; use and satisfaction

\section{INTRODUCTION}

Given the ageing population, a surge in the amount of older people puts forward unprecedented demand for diverse development of home-based services supply. According to the goal of the Chinese government, $90 \%$ of the older population will be spending their old age at home in the future. The most effective ways of achieving these goals are to increase the number of service suppliers and to develop the diversity of service deliveries. PPP has been adopted in the services provision system for older people as the number of older people increased sharply around the world.

As a result, scholars on the private sector provision of home-based services for older peopleare conducting a wide range of research. International articles have put forward the necessity of the cooperation between the public and private sectors. Savas, for example, shows that the government is responsible to choose service providers, to arrange service content and to supervise the service quality based on the New Public Management Theory[1]. Evans and Shields indicate that the private sector is not only a complement to the public but also equal partner. PPP helps to improve the status of the private sector[2].Kotler points out that the private sector brings forth new ideas and enables flexibility so that the diverse need of older people can be better considered[3]. Wettenhall takes PPP as an example to indicate that cooperation between the public and the private sectors can optimize the allocation of resources and improve the overall planning ability of the government[4].In contrast,

1.Savas, E.S. Privatization and the new public management. Fordham Urb 2000, 28, 1731.

Available online: http://heinonline.org/HOL/LandingPage?handle=hein.journals/frdurb28\&div=55\&id=\&page= 2.Evans,B. M., Shields,J. Neoliberal Restructuring and the Third Sector: Reshaping Governance, Civil Society and Local Relations. Working Paper, Centre for Voluntary Sector Studies, Ryerson University, 2000.

3.Kotler, P., Murray, M. Third sector management-The role of marketing. Public Administration Review 1975, 35,467-472. Available online:http://www.jstor.org/stable/974176?seq=1\#page_scan_tab_contents

4.Wettenhall, R. The rhetoric and reality of public-private partnerships. Public Organization Review2003, 3,77107. Available online:https://link.springer.com/article/10.1023/A:1023000128175 


\section{Rui Kang et al.}

some scholars have expressed concerns about the participation of the private sector. According to the Traditional Welfare Economics, public service provision is the natural duty of a government department. Moreover, the government is the only provider because the service capability of the private sector is rather limited [5].Concerning the benefit of the government, Corbettpoints out the query of the transaction cost in the process of PPP; he also clarifies that the government is at a disadvantage because of its more rigid economic system if the private sector is brought into the market [6]. Chanalso declares thatthe revenue in PPP cannot meet its expenditure[7]. Concerning private sectors, they are faced with market, management, operation andincome risks in cooperating with the public sector. Experts also have their own evaluation index system showed to support their debate on the use of services for older people. Some scholars argue about the factors influencing social care conditions of older people. Psycho-social determinants (e.g. income, health-related behaviors, social exclusion and poverty) affect a great amount with respect to the need and consequent use of services. Use of social care services is dependent on socio-economic status (SES) or social capital. The older people who are lower in term of SES are less likely to discuss health issues or have access to support groups [8].

Researchers in China concentrate on how to promote the collaboration from a theoretical perspective rather than via practical research. Most specialists and scholars recommend the private sector enlarge the scale of the services for older people. Mudemonstrates that it is essential to carry forward the government's financial contribution[9]. Su proposes establishing of a legal system to regulate the government's purchasing social care services ${ }^{[10]}$.Guosuggests bringing quality supervision and the index system into the whole development plan of services for older people and setting up a third-party evaluation and audit system[11].

According to the research literature above, although the results vary among different methods and discipline background adopted, they overlook an important perspective. It is the older people who receive the service ultimately. Most of the previous research in macroeconomics has explored the impact of PPP on both public and private sectors rather than consider the perspective of the older people. User channel is difficult to be foundin the previous articles. The way to better understand the effect of the private sector provision of home-based services for older people is the response from the individuals. Our research specially addresses these challenge. In order to allow the older people to enjoy home-based services at home and achieve well-being for the rest of their lives, the research focuses on how to make full use of the private sector according to the demand of the older people. Consequently, we aim to investigate the impact of PPP on the use of and satisfaction with home-based services using survey data in 2015.

5.Hume, D. A Treatise of Human Nature; Courier Corporation: Massachusetts, US. 2012;pp.162-163.

6.Corbett, P., Smith, R. An Analysis of the Success of the Private Finance Initiative as the Government's Preferred Procurement Route, Proceedings of the Accelerating Excellence in the Built Environment Conference, Birmingham, UK, 2006.

7.Chan, D.W.M., Chan, A. P. C., Lam, P. T. I.A. Feasibility Study of the Implementation of Public Private Partnership (PPP) in Hong Kong, Proceeding of the CIB W89 BEAR 2006 International Conference on Construction Sustainability and Innovation, Hongkong, 2006.

8.Bell, A. V. "I Think About Oprah" Social Class Differences in Sources of Health Information. Qualitative Health Research 2014.24, 506-516.Available online: https://www.ncbi.nlm.nih.gov/pubmed/24623661

9.Guangzong, M. China's Institutional Pension Difficulties and Countermeasures in the Development of Aging services. Journal of China Central Normal University2012, $2: 31-38$. (In Chinese) Available online:http://kns. cnki.net/KCMS/detail/detail.aspx?dbcode=CJFQ \&dbname=CJFD2011\&filename=HZSD201105007\&v=MTU3 NTRxVHJXTTFGckNVUkwyZllPZHJGQ2ptVWIzQUxUZllhckc0SDIETXFvOUZZNFI4ZVgxTHV4WVM3 RGgxVDM=

10.Su, M., Jia, X., Sun J., Han, J.K. China's Government Purchase of Public Services Research. Journal of Financial Research 2010,1, 9 - 17.(In Chinese) Available online:http://kns.cnki.net/KCMS/detail/detail.aspx? dbcode $=C J F Q \& d$ dbname $=$ CJFD2010\&filename $=C Z Y J 201001004 \& v=$ MDUwMDdTNORoMVQzcVRyV00xRn JDVVJMMmZZT2RyRkNqbVdyckpKamZTWkxHNEg5SE1ybzlGWUISOGVYMUx1eFk=

11.Guo, L. Typical Western Countries Private Capital Participation in Pension Service System Construction Journal of Social Science Abroad 2014,6, 47-54.(In Chinese) Available online:http://kns.cnki.net/KCMS/detai 1/detail.aspx ?dbcode $=$ CJFQ \&dbname $=$ CJFDLAST2015\&filename $=$ GWSH201406007\&v $=$ MDAyMzNDam5Vc npBSWpyWVpyRzRIOVhNcVk5Rlk0UjhlWDFMdXhZUzdEaDFUM3FUcldNMUZyQ1VSTDJmWU9kckY= 
This paper includes the following parts: Section 2 sets out the history and current condition of the cooperation between public and private sectors to supply home-based services for older people in Beijing which leads to some of the hypotheses; Section 3 shows the hypotheses and research questions and discusses the factors affecting the use of and the satisfaction with the services the older people achieve; Section 4 offers data from China's survey and builds data models to examine whether contribution of both the government and the private sector, and personal characters affect the share of home-based services that the older people obtain and how they feel about these kinds of services; Section 5 offers some concluding remarks.

\section{Private Sector Provision of Home-based Services for Older People in BEIJING}

PPP is classified into three forms under laws and guidance rules of Beijing: Voucher system, Government Grants or Subsidies, and Public Builds \&Private Operates. The public and private sectors participate with different roles in each of different types; divisions of responsibility between them are made in a variety of ways. The following section outlines discriminating characteristics of each form and examines how they cooperate to supply home-based services for older people in Beijing.

\subsection{A Voucher System}

The Beijing government published Home-based (Disability-assistive) Services Methods, which is called Nine Policies for Older Care in 2009. There are nine categories of people who are eligible to receive the government-subsidized voucher, including older people (aged 80 and over), disabled people, and those without children, which are called Special Old Person. They are paid a 100 yuan RMB (equal to $\$ 15.3$ USD) voucher per month by the public finance. The voucher is used to pay for home-based services, such as housekeeping and food delivery. Approximately 450,000 older people were covered by this policy, which accounts for $87.2 \%$ of all the older population over 80 at the beginning of the establishment. The program has been extended to include 60-79 years olds in some districts in Beijing as well since 2011. Furthermore, the value of the voucher has increased from 100 yuan to 200 yuan (equal to 30.6 USD). They can buy food, have a haircut and enjoy social care services using the voucher within the private institutes specified by the government. The voucher's stipend, compared with the daily output of each older person, 1,366 yuan RMB (equal to 208.44 USD) per month on average, helps this demographic in a rather limited way, as showed in Table 1. [122]

Table 1. Household economies and subsidy for the older people in Beijing.

\begin{tabular}{|l|l|l|}
\hline \multicolumn{1}{|c|}{ Index } & \multicolumn{1}{c|}{ Average } & \multicolumn{1}{c|}{ Older people } \\
\hline Per capita consumption expenditure ( yuan/monthly ) & 3,088 & 1,367 \\
\hline Per capita disposable income ( yuan/monthly ) & 4,853 & - \\
\hline Government-subsidized voucher ( yuan/monthly ) & & 200 \\
\hline Pension ( yuan/monthly ) & & 3,050 \\
\hline
\end{tabular}

\subsection{Government Grants or Subsidies}

Government Grants or Subsidies are derived from the Welfare Lottery Ticket Public Fund and the Social Security Fund in Beijing. The Civil Affairs Bureau in each district makes plans and apportions the finance to apportions the finances to the local authority. In Beijing, older people go to the care center where there are nursing beds and luncheon clubs for older people; these facilities are located in the center of residential area. The workers help the older people to ensure that their lives are made easier in the professional social organizations. It is the local authority's task to supply a pager or telephone in older people's homes with a grant from the central government. As of 2014, there were 18,600 nursing beds in the neighborhood and 3429 luncheon clubs for older people in Beijing[13]. Rehabilitation services are applied to the beds only used in the daytime. Older people can enjoy three

12.Report of Beijing Older Population Information and Development Status in 2014. Available online at http://zhengwu.beijing.gov.cn/tjxx/tjgb/t1412150.htm

13.Report of Beijing Older Population Information and Development Status in 2014. Available online at http://zhengwu.beijing.gov.cn/tjxx/tjgb/t1412150.htm 
meals a day there or have take-outs delivered to their homes. Private catering companies are in charge of making all the meals and delivery.

\subsection{Public Builds and Private Operators}

The government established this kind of service and asked private organizations to bid for the running of it. The unit that wins the tender has the responsibility to train the caregivers and provide skilled care service for older people who call the hot line. A total of 4400 caregivers have been trained since 2014. The government also developed insurance for older people who are taken care of at home with the commercial insurance companies. Both of them provide money and design for the insurance products. Each insurance costs for 17 yuan RMB (equal to \$2.59 USD) annually The commercial insurance companies provide a discount for the older people who pay by themselves. The insured older people can achieve at most 0.2 million yuan (equal to $\$ 30,376$ USD) compensation one year if they suffer death, disability, or burns when taking the municipal transportation or in the public area.

In conclusion, the government programs and formations of PPP are integral but are still in their beginning stages. The Voucher System is the most popular among the older people because it is totally paid by the government and free for the individual, they are more able to choose the services on their own. However, it is difficult for the government to monitor the process of voucher issue and the diversity of service providers. In the model of government grants or subsidies, a large amount of facilities are built by the government, which are crucial to the long-term development. Due to lack of professional staff, the services older people get, however, are limited and they do not feel extremely satisfied with the services that private organizations offer, both in terms of the quality and quantity. Public builds and Private operators is a new emerging pattern and private sector's participating awareness is weak. In addition, the division of responsibility between the public and private sectors is ambiguous mking it less efficient than the other two models.

\section{HYPOTHESES AND DATA}

\subsection{Therotical Framework}

According to Samuelson's Theory of Government failure, although the government plays an important role in providing the public product, which is not available in the market price mechanism, government failure cannot be handled successfully. Government failure is absence of efficient, resulting from the fact that the government is not able to achieve all the information whether people need the public product or not. Under such circumstances, the private sector's participation becomes particularly important. [14]Social welfare can be seen as public product in the Public Economics and it should be provided by the whole society, including government, social organizations and individual. The development consumption of social welfare is as follows:

$S W=\beta_{1} *$ Public $+\beta_{2} *$ Private $+\lambda(1)$

$S W$ stands for the achievement of social welfare; Public and Private represent the contribution of government and private sector.

$S W=\beta_{1} *$ Public $+\beta_{2} *$ Private $+\beta_{3} *$ Individual $+\lambda$

In addition, Weimer and Vining note that production and distribution of goods depends on both public choice and personal choice. [15] Based on the Equation (1), individuals can be the participant subject; Individual represents individuals or their families' contribution.

\subsection{Data Models}

According to the theories mentioned above, we assume that older people's access to home-based services depends on the resources they have, which is supported by the government, the private sector and themselves even their family. Use of home-based services for older people is affected on the one hand by the finance, regulations, private sector conditions, and an individual's situation on the other hand. Older people's satisfaction with the home-based services is affected by the same factors. He and

14.Samuelson, P. A. Economics.McGraw-Hill,2000. .

15. Weimer D L, Vining A R.Policy analysis :concepts and practice.Journal of Policy Analysis \&

Management1989. 9.Available online:https://is.muni.cz/publication/675394

International Journal of Research in Sociology and Anthropology (IJRSA)

Page $\mid 24$ 
Wu investigated the use of ordinary least squares (OLS) in their research of determining the relationships between health care resource utilization and direct medical costs for patients and found the OLS is superior to other options [16]. Hardie also applied the OLS regression analyses to examine the relationship between behavioral health services use and outpatient intensity measures and achieve the robust outcome [17].To estimate the impact of the private sector provision of home-based services for older people, we use multiple regression estimated with OLS. Based on the theoretical framework discussed above, we construct the basic data models with the individual-effect as follows:

Use $_{i}=\beta_{0}+\beta_{1}$ Finance $_{i}+\beta_{2}{\text { Re } \text { gulation }_{i}+\beta_{3} \text { PSector }_{i}+\beta_{4} \text { PStaff }_{i}+\beta_{5} \text { Pension }_{i}}$

$+\beta_{6}$ Expenditur $_{i}+\beta_{7}$ Income $_{i}+\beta_{8}$ Demographics $_{i}(i=1,2 \ldots, N)$

Let Use be the older people use of the home-based services. It is the ratio of people who have used the service to all the respondents. Finance means the amount of money the local authorities pay for older people and the private sector; Re gulation shows whether there are regulations or laws to prompt PPP in home-based services for older people; PSector indicates the quantity of private organizations which can provide home-based social care services in the local area and also contract with the local authority; ${ }^{\text {Staff }}$ indicates the number of professional staffs, including nurse practitioners and caregivers who belong to the private sector. In terms of the individual economics resource, let Pension mean the old individual's pension every month, Expenditure be older people's living expense. Income indicates the whole family's indicators. Demographics includes older people's age, gender, self-care ability, health status, marital status, the number of children, and so forth. $\mathrm{N}$ is the sample size.

$$
\begin{aligned}
& \text { Satisfaction }_{i}=\beta_{0}+\beta_{1} \text { Finance }_{i}+\beta_{2}{\text { Re } \text { gulation }_{i}}+\beta_{3} \text { PSector }_{i}+\beta_{4} \text { PStaff }_{i}+\beta_{5} \text { Pension }_{i} \\
& +\beta_{6} \text { Expenditur }_{i}+\beta_{7} \text { Income }_{i}+\beta_{8} \text { Demographics }_{i}(i=1,2 \ldots, N)
\end{aligned}
$$

Let Satisfaction be the evaluation of older people on the home-basedservice they use. Other variables are the same in the Equation (3), as demonstrated by Equation (4).

\subsection{Data and variables}

The statistics data in 2015 can be collected from the statistics offered by the Chinese National Bureau of Statistics, Beijing Bureau of Statistics, and Civil Affairs Bureau. The statistic data include the local authority finance into the PPP, the amount and scale of the domestic private companies, the amount of nurses and caregivers in every district of Beijing.

The Yinian Older Care Promotion Center conducted survey in the summer of 2015, covering698 respondents living in Beijing and aged over 60 years. The survey was with respect to respondents' personal characteristics and the home-based services they enjoyed.

Respondents' personal characteristics included age, gender, self-care ability, health condition, marital status, the number of children, individual pension and expenditure, and family's income. Self-care ability was measured by some activities showed on the questionnaire. The interviewee could choose what activities they could do, such as having a meal by themselves. Each activity generated a different score and our data takes the sum of all these scores. Health condition is self-evaluated by the old person who is given five levels to choose, ranging from very good, good, general, poor and very poor.

\footnotetext{
16.He X, Wu J, Jiang Y, et al. Health care resource utilization and direct medical costs for patients with schizophrenia initiating treatment with atypical versus typical antipsychotics in Tianjin, China. Bmc Health Services Research2015.15:149. Available

online:http:/ / xueshu.baidu.com/s?wd=Health+care+resource+utilization+and+direct+medical+costs+for+patie nts+with+schizophrenia+initiating+treatment+with+atypical+versus+typical+antipsychotics+in+tianjin $\% 2 \mathrm{C}+\mathrm{chi}$ na\&rsv_bp=0\&tn=SE_baiduxueshu_c1gjeupa\&rsv_spt=3\&ie=utf-

$8 \& \mathrm{f}=8 \&$ rsv_sug2=0\&sc_f_para=sc_tasktype \%3D\%7BfirstSimpleSearch\%7D

17.Hardie, N. A., Lo Sasso, A. T., Shah, M., \& Levin, R. A. . Behavioral healthcare services use in health savings accounts versus traditional health plans. J Ment Health Policy Econ2010. 13: 159-165.Available online:http:/ / xueshu.baidu.com/s?wd=+Behavioral+healthcare+services+use+in+health+savings+accounts+ver sus+traditional+health+plans.\&rsv_bp=0\&tn=SE_baiduxueshu_c1gjeupa\&rsv_spt=3\&ie=utf$8 \& \mathrm{f}=8 \&$ rsv_sug2=0\&sc_f_para=sc_tasktype \%3D\%7BfirstSimpleSearch\%7D
} 


\section{Rui Kang et al.}

There are 20 kinds of services provided by the private sector in total. We divide them into practical help and personal care. The practical help includes day center, hourly worker, shopping, washing clothes, pipeline dredge, appliance repairing, indoor cleaning, water and electricity installation maintenance service, sightseeing, university for older people and training for older people. Personal care includes assistance with drug administration, haircut, bath assistance, psychological counseling, chatting and recreation, family health service, skilled care service, periodic health examination and accompanied doctor visits. All the respondents are asked "Overall, how satisfied are you with the home-based services you receive?" Satisfaction is categorized intofive levels: (1) extremely satisfied; ( 2) satisfied ; (3) medium ; (4) dissatisfied; ( 5) extremely dissatisfied. The variables were assigned 1-5 points. The use of and the satisfaction with the home-based services for older people are calculated in the following table.

Table 2. Means of dependent variables by category of demographic.

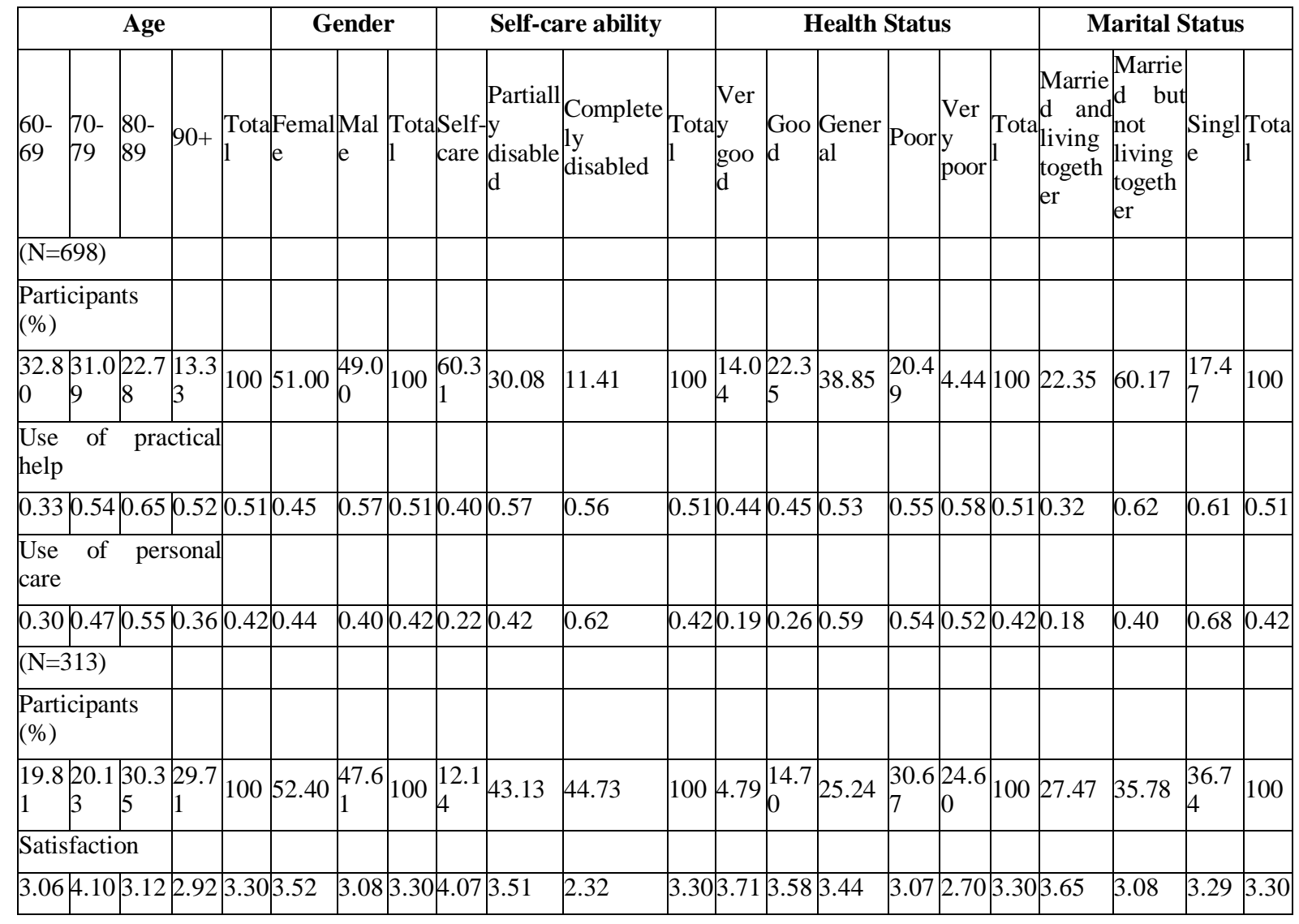

A For the use of both two kinds of services, there are inverse U shapes when it comes to the age. Older people between 80 and 89 years of age use more services than any other age bands. It can be seen from the chart above that older women tend to use practical help less frequently than older men. Women in the study reported higher use of the personal care services than men. Older people are more available to the home-based services with the decrease in level of health. In terms of the self-care ability, the partially disabled and the completely disabled people use the practical help and the personal care most frequently. There is a remarkably low level of utilization of personal care services with only $22 \%$ of them are used by the older people with extremely good health status. In accordance with common assumptions, people who are married and also living together use such services the least and those who are single use them the most.

Satisfaction with the home-based services fluctuates steadily as the age increases. It is apparent from the figures that the older women feel more content than older men. Although a considerable increase occurs among the 70-79 years old, it reduces soon after 80 years of age. Satisfaction has a similar trend with the self-care ability and health status. Completely healthy older people rate the services they achieve at a higher level than other groups. In other words, it comes down when the physical condition goes worse. However, there is not a great deal of difference among different marriage statuses. 
The Impact of Private Sector Provision of Home-Based Services for Older People in Beijing

According to the data models, variables of interest are summarized and defined in Table 3.

Table 3. Definition of the variables.

\begin{tabular}{|c|c|c|c|}
\hline & Variables & Symbol & Definition \\
\hline \multirow{2}{*}{ Use } & Use of practical help & $\begin{array}{l}\text { Use of practical } \\
\text { help }\end{array}$ & $\begin{array}{l}\text { It is the proportion of the services older } \\
\text { people have used out of all11 kinds of } \\
\text { practical help services. }\end{array}$ \\
\hline & Use of personal care & $\begin{array}{l}\text { Use of personal } \\
\text { care }\end{array}$ & $\begin{array}{l}\text { It is the proportion of the services older } \\
\text { people have used out of all9 kinds of } \\
\text { personal care services. }\end{array}$ \\
\hline Satisfaction & $\begin{array}{l}\text { Older people's satisfaction with Home-based } \\
\text { services }\end{array}$ & Satisfaction & $\begin{array}{llr}\text { Great dissatisfaction:1 } & \text { Dissatisfaction:2 } \\
\text { General:3 } & \text { Satisfaction:4 } & \text { Great } \\
\text { Satisfaction:5 } & & \end{array}$ \\
\hline \multirow{2}{*}{ Public sector } & $\begin{array}{l}\text { Local authority financing of PPP in home- } \\
\text { based services for older person and the } \\
\text { private sector(yuan/yearly) }\end{array}$ & Finance & $\begin{array}{l}\text { Local authority financing includes the } \\
\text { vouchers, grants and other payments to the } \\
\text { individual and the private sector; it is } \\
\text { divided by the amount of older people in } \\
\text { the local area. }\end{array}$ \\
\hline & $\begin{array}{l}\text { Regulations for PPP in home-based service } \\
\text { for older people }\end{array}$ & Regulation & $\begin{array}{l}\text { Regulations refer to regulations or laws to } \\
\text { promote the PPP in home-based service for } \\
\text { older people, for example, tax preference } \\
\text { policy for the private sector. } \\
\text { Inexistence: } 0 \text { Existence: } 1\end{array}$ \\
\hline \multirow[t]{2}{*}{ Private sector } & Coverage of the private sector & Private sector & $\begin{array}{l}\text { The private sector includes the company or } \\
\text { organization, which cooperates with the } \\
\text { public and can provide home-based } \\
\text { services in the local district. Coverage } \\
\text { means the amount divided by the older } \\
\text { population. }\end{array}$ \\
\hline & Coverage of professional staffs & Staff & $\begin{array}{l}\text { Professional staffs include nurse } \\
\text { practitioners and caregiverswho belong to } \\
\text { the private sector in the local district. } \\
\text { Coverage means the amount divided by the } \\
\text { older population. }\end{array}$ \\
\hline \multirow[b]{2}{*}{ Individual } & Older people's pension(yuan/monthly) & Pension & $\begin{array}{l}\text { The pension older people achieve every } \\
\text { month. It ranges among different } \\
\text { occupations. }\end{array}$ \\
\hline & $\begin{array}{l}\text { Older people's expenditure individually } \\
\text { (yuan/monthly) }\end{array}$ & Expenditure & $\begin{array}{l}\text { Expenditure covers clothes, food, health } \\
\text { care, social care service, communication, } \\
\text { transp ortation, entertainment and other } \\
\text { daily output. }\end{array}$ \\
\hline Family & Household income (yuan/monthly) & $\begin{array}{l}\text { Household } \\
\text { income }\end{array}$ & $\begin{array}{l}\text { Household income covers household wage } \\
\text { income and individual-based transfers, self- } \\
\text { employed activities and household public } \\
\text { transfer income. The family's income is } \\
\text { divided by the number of household } \\
\text { members. }\end{array}$ \\
\hline \multirow{6}{*}{ Demographics } & Age & Age & $\begin{array}{l}\text { Recipients' actual age filled in the in } \\
\text { questionnaire. }\end{array}$ \\
\hline & Gender & Gender & Female:0 Male:1 \\
\hline & Self-care ability & Health & $\begin{array}{l}\text { Self-care:1 Partially disabled:2 Completely } \\
\text { disabled:3 }\end{array}$ \\
\hline & Health status & Health & $\begin{array}{l}\text { Very good:1 Good:2 General:3 Poor:4 } \\
\text { Very poor:5 }\end{array}$ \\
\hline & Marital status & Marital & $\begin{array}{l}\text { Married and living together:1 } \\
\text { Married but not living together:2 Single:3 }\end{array}$ \\
\hline & The number of children & Children & $\begin{array}{l}\text { The number of adult children who } \\
\text { accompany the older people. }\end{array}$ \\
\hline
\end{tabular}

\section{ReSUlt OF ANAlysis}

\subsection{Descriptive Statistics}

According to the statistics data found on the website and the survey questionnaire, descriptive statistics of the variables are summarized in Table 4. After the correlation analysis, we cut the variables self-care ability and marital status because of multiple multiplicity. 
Rui Kang et al.

Table 4. Descriptive statistics of variables.

\begin{tabular}{|c|c|c|c|c|c|}
\hline & Numbers of observations & Mean & Standard Deviation & Minimum & Maximum \\
\hline \multicolumn{6}{|l|}{ Dependent variables } \\
\hline Use of practical help & 698 & 0.51 & 0.07 & 0.00 & 0.70 \\
\hline Use of personal care & 698 & 0.42 & 0.05 & 0.00 & 0.66 \\
\hline Satisfaction & 313 & 3.30 & 0.96 & 1.00 & 5.00 \\
\hline \multicolumn{6}{|c|}{ Independent variables } \\
\hline Finance & 698 & 210.43 & 30.23 & 185.61 & 270.00 \\
\hline Regulation & 698 & - & - & $0(65 \%)$ & $1(35 \%)$ \\
\hline Private sector & 698 & 16.61 & 5.47 & 8.92 & 23.60 \\
\hline Staff & 698 & 22.26 & 15.36 & 7.00 & 49.00 \\
\hline Pension & 698 & 5858.93 & 3719.35 & 0.00 & $70,000.00$ \\
\hline Expenditure & 698 & 1083.96 & 2027.06 & 0.00 & $21,966.67$ \\
\hline Household income & 698 & 10382.94 & 29583.1 & 0.00 & $200,000.00$ \\
\hline Age & 698 & 69.35 & 7.41 & 60.00 & 85.00 \\
\hline Gender & 698 & - & - & $0(54 \%)$ & $1(46 \%)$ \\
\hline Health & 698 & 2.61 & 0.82 & 1.00 & 5.00 \\
\hline Children & 698 & 3.16 & 0.5 & 0.00 & 6.00 \\
\hline
\end{tabular}

As is seen in Table 3, 698 older people are interviewed in which 313 of them have used oneor more kinds of home-based services provided by the private sector. The maximum use is $70 \%$ and the minimum is $40 \%$. For the satisfaction with the services, the mean is 3.25 and difference is not obvious enough among the whole subjects. We will take the base-10 logarithm of finance, pension, expenditure and household income in order to avoid biased estimation from the extremely large amount.

\subsection{The Impact on the use of Home-based services for older people}

Based on the framework equation (3) above, we construct the following models to find the connection between the use of home-based services for older people and other factors. Table 4 shows the outcome of multiple regressions. According to the F test in the model, $\mathrm{P}$ is 0.001 and standard $\mathrm{F}$ statistic is significant at the $1 \%$ level, which means the linear relationship in the model is outstanding and the effect does exist. When it comes to the test result of the goodness of fit in the equation, the adjusted R2 values are 0.9788 and 0.9167 , which shows that the model's fit is high. The DurbinWatson (DW) values are 2.395 and 2.219, which verify the absence of autocorrelation among the independent variables.

Table 4. Estimation of the impact on the use of home-based services for older people.

\begin{tabular}{|l|l|l|}
\hline Variables & Use of practical help & Use of personal care \\
\hline Finance & $-0.437(0.041)$ & $-0.782(0.405)$ \\
\hline Regulation & $1.035^{* *}(0.059)$ & $1.006^{* *}(0.047)$ \\
\hline Private sector & $0.003(0.002)$ & $0.009(0.007)$ \\
\hline Staff & $-0.126(0.054)$ & $-0.076^{* *}(0.042)$ \\
\hline Pension & $-0.010^{* *}(0.043)$ & $-0.004^{* *}(0.003)$ \\
\hline Expenditure & $-0.012(0.050)$ & $-0.003(0.031)$ \\
\hline Household income & $2.830(0.060)$ & $2.438(0.028)$ \\
\hline Age & $0.238^{*}(0.002)$ & $0.814(0.030)$ \\
\hline Gender & $1.234(0.049)$ & $1.763(0.010)$ \\
\hline Health & $-0.001(0.021)$ & $-0.002(0.068)$ \\
\hline Children & $-2.130^{* *}(0.022)$ & $-3.240 * * *(0.044)$ \\
\hline cons & $-2.12(0.003)$ & $-3.89(0.052)$ \\
\hline Adjusted $\mathrm{R}^{2}$ & 0.9788 & 0.9167 \\
\hline F & 156.90 & 110.37 \\
\hline P & 0.001 & 0.001 \\
\hline
\end{tabular}

From the analyzed outcome in Table 5, we can conclude that there are five kinds of factors that affect the use of both the practical help and personal care services provided by the private sector. Coverage of private sectors and older people's pension affect the use positively. The use of home-based services 
is higher in the districts where the extra regulation on subsidy for older person and the private sector is available. On the contrary, with the increase in the number of their children, the use comes down. Moreover, people are more likely to use the practical help service as the age increases. Other factors have no evident correlation with the use. We also find a negative correlation between the coverage of professional staffs and the use of the personal care services.

\subsection{The Impact on the Satisfaction with Home-Based Services for Older People}

Apart from the use, another important indicator to examine PPP is older people's evaluation. Likewise, based on the framework equation (3) above, we construct the following model to find the connection between user satisfaction with home-based services and other factors. Table 6 shows the outcome of multiple regressions. According to the $\mathrm{F}$ test in the model, $\mathrm{P}$ is 0 and standard $\mathrm{F}$ statistic is significant at the $1 \%$ level, which means the linear relationship in the model is outstanding and the effect does exist. When it comes to the test results of the goodness of fit in the equation, the adjusted R2 value is 0.7315 , which shows that the model's fit is high. The (DW) value is 2.117 that verifies the absence of autocorrelation among the independent variables.

Table 6. Estimation of the impact on the satisfaction with home-based services for older people.

\begin{tabular}{|c|c|c|c|c|c|c|}
\hline Variables & Coef. & SE & $\mathbf{T}$ & $\mathbf{P}$ & \multicolumn{2}{|c|}{$95 \% \mathrm{CI}$} \\
\hline Finance & 0.005 & 0.002 & 2.68 & 0.000 & 0.001 & 0.009 \\
\hline Regulation & 0.001 & 0.000 & 5.90 & 0.000 & 0.001 & 0.001 \\
\hline Private sector & 0.021 & 0.002 & 8.94 & 0.000 & 0.016 & 0.026 \\
\hline Staff & -0.402 & 0.085 & -4.73 & 0.000 & -0.569 & -0.235 \\
\hline Pension & 0.712 & 0.691 & 1.03 & 0.303 & -0.643 & 2.067 \\
\hline Expenditure & 0.126 & 0.035 & 3.59 & 0.000 & 0.057 & 0.195 \\
\hline Household income & -1.197 & 3.741 & -0.32 & 0.749 & -8.529 & 6.135 \\
\hline Age & -2.027 & 2.502 & -0.81 & 0.419 & -6.932 & 2.878 \\
\hline Gender & 0.002 & 0.003 & 0.60 & 0.548 & -0.005 & 0.009 \\
\hline Health & -3.788 & 2.892 & -1.31 & 0.190 & -9.456 & 1.880 \\
\hline cons & 116.2 & & & & & \\
\hline Adjusted $\mathrm{R}^{2}$ & & & & 0.7315 & & \\
\hline $\mathrm{F}$ & & & & 186.06 & & \\
\hline $\mathrm{P}$ & & & & 0.000 & & \\
\hline
\end{tabular}

As demonstrated in Table 6, the coefficients of finance, regulation, private sector, pension and expenditure are positive, which implies that the satisfaction of older people increases when the finance of the local authority, regulation of subsidies, coverage of the private sector and older people's individual expenditure are additive. The areas where there are extra subsidy regulations for older people or the private sector are more likely to raise the satisfaction.

\section{CONCLUSION}

\subsection{Main Findings}

This article has focused on home-based services for older people provided by the private sector via the user channel. Using the latest data, we are able to measure the result of PPP. Older people's use of and satisfaction with home-based services are influenced by both of effectiveness of PPP and personal characteristics. In conclusion, the use of home-based services depends on the government's contribution as well as the older person's financial resources and family structure. On the other hand, the satisfaction older people with respect to the services they have used is influenced by support from local authority and private sectors. It also has a lot to do with older person's expenditures and pension.

\subsection{Discussion of Findings}

This study presents the development of PPP from the perspective of home-based service recipients and aims to determine improved methods of service provision in Beijing. On the basis of Samuelson's Theory of Government Failure, we hypothesize that the use of, and satisfaction with the services provided by the private sector are influenced by government funding and regulation, the coverage of 


\section{Rui Kang et al.}

the private sector and its professional staff, economic resources and other demographics of the individuals, and family backgrounds.

Second, the results indicate that the use of and satisfaction with home-based services for older people provided by the private sector are positively correlated with the economic stability of the service users. Although additional subsidy is provided in some pilot areas of Beijing, only a modest proportion of the individual cost is covered. Physiological needs become more important when the resources of an individual are limited. Indeed, most respondents state that the pension they receive only covers daily necessities and medical expenditures, at best. Influenced by traditional customs, older people in China prefer to save rather than consume. [18] Affluent older people prefer to save the balance to support their children at the expense of their well-being; with limited money, they cannot afford high-quality services.

In addition, the use varies across different levels according to the number of children of older people. Specifically, vouchers and subsidies provide a one-size-fits-all solution without stratification: they cannot be adjusted according to various types of family structure. The kind of help needed by older people from the private sector and its affiliates vary according to their number of children. For homebased services, the functions of the family and the private sector are complementary. For some bereaved parents or older people who live far away from their children, more resources should be provided to pay for the home-based services; this is the group with urgent need.

User satisfaction with services increases when the devotion of the public sector is added. As PPP is now in the early stage, the coverage of the private sector specializing in home-based services for older people remains limited. Thus, some unhealthy phenomena exist: the emergence of seller's market raises the price of care service, thereby restricting consumer choice. In addition, older people have to wait in line for an extended time only to receive in adequate service and their needs are not addressed immediately. Some private companies experience significant difficulty in recruiting personnel, particularly staff specialized in home care. Therefore, the level of satisfaction declines because of poor service quality.

What implications we could obtain from the analysis are as follows: The existing private sectors should expand the scale to improve their services. With the support of local authorities, they should be encouraged to train professional caregivers who should be provided with proper facilities to meet the diverse needs of older people. This is because our analyses suggest that coverage of private sector and professional staffs have a positive effect on the service use and estimation. We also recommend increasing financial support to individuals and building a hierarchical voucher system of home-based services for older people. Our finding is applicable to certify that the family support and service provided by the private are complementary. The implication for future policy-making is that a survey has to be conducted to ascertain the care available for older people by themselves or from their families before any extension. As discussed earlier, the number of children could be used as a potential assessment indicator.

\subsection{Limitations}

This study has several limitations. First, we examined, primarily, the variables closely related with the use of and satisfaction with the home-based services provided by the private sector for older people. However, the degree of improvement remains uncertain. Consequently, we cannot precisely calculate the ideal public or private investments required to fully satisfy the demands of older people. In addition, the level of satisfaction is evaluated by older people, although the recipients may choose from five levels given. The standards may vary among different individuals. Expanding the sample size is suggested to ensure the objectivity and effectiveness of the model.

18. Modigliani F, Cao S L.The Chinese Saving Puzzle and the Life-Cycle Hypothesis. Journal of Economic Literature2004.42:145-170.Available online :http://www.sciencedirect.com /science/article/pii/ S1043951X 10000994 


\section{ACKNOWLEDGMENTS:}

This research is supported by the China Scholarship Council. The first author would like to appreciate the studying experience provided by the Oxford Institute of Population Ageing and would like to thank George Leeson from the institute for his helpful suggestions for the research. Special thanks are also due to Cheng Zhang from the University of Oxford and Hua Jiang from Capital University of Economics and Business for their kind guidance on data mining and proofreading. Lastly we acknowledge the support from the SUHC team from Capital University of Economics and Business for all the data provided and interactions online.

Citation: Rui Kang George Leeson \& Laurel Hixon" The Impact of Private Sector Provision of HomeBased Services for Older People in Beijing" International Journal of Research in Sociology and Anthropology (IJRSA), vol 3, no. 4, 2017, pp. 21-31. doi:http://dx.doi.org/10.20431/2454-8677.0304003.

Copyright: (๑) 2017 Authors. This is an open-access article distributed under the terms of the Creative Commons Attribution License, which permits unrestricted use, distribution, and reproduction in any medium, provided the original author and source are credited. 